\title{
E-Commerce Products and Services in the Banking Industry: The Adoption and Usage in Commercial Banks in Kenya
}

\author{
Peterson Obara Magutu ${ }^{1}$, Michael Mwangi ${ }^{1}$, Richard Bitange Nyaoga ${ }^{2}$, Gladys Monchari \\ Ondimu $^{1}$, Margaret Kagu ${ }^{1}$, Kipngeno Mutai ${ }^{1}$, Henry Kilonzo ${ }^{1}$ and Peninah Nthenya ${ }^{1}$ \\ ${ }^{1}$ Department of Management Science, School of Business, University of Nairobi, Nairobi - Kenya \\ ${ }^{2}$ Department of Management Science, School of Business, Narok University College, Nairobi - Kenya
}

\begin{abstract}
Globalization, collaboration and wireless technologies have led to stiff competition. As a result, commercial banks have generally adopted the use of e-commerce products and services in their delivery of services to customers. This study's main objective was to explore the challenges faced and benefits that accrue from adoption and usage of e-commerce products and services banking by commercial banks in Kenya. A survey was carried out to achieve the envisaged aims of the study. A total of 100 questionnaires were distributed however only 70 banks responded. Overall, research showed that while the majority of the banks in Kenya have adopted e-commerce products and services, usage levels have remained relatively low, as not many customers are using this innovation in Kenya.
\end{abstract}

To establish benefits and challenges in the adoption and usage of e-commerce, 32 variables were used to measure the level of application among these banks. These variables were analyzed using factor analysis procedure and in order to achieve a simple and meaningful structure, that is, have a nonzero loading of the explained variance for each individual factors, varimax rotation was done. As a result, 10 critical factors were established as the best practices which include: improved customer service, reduced number of customers in the banking hall, reduced operating costs and increased market share. The challenges faced in the adoption of e-commerce products and services include compatibility with existing legacy systems, cost of implementation and security concerns ranked high, ensuring desired levels of security and privacy. Unreliable telecommunication as well as lack of legislation governing e-commerce transactions rated highly.

Keywords: e-commerce, e-commerce products and services, benefits and challenges, commercial banks

\section{Introduction}

\section{Background}

E-commerce is a commercial activity dealing directly with the trading of goods and services and with other related business activities, in which the electronic communication medium plays a central role. These activities include the communication of information, the management of payment, the negotiating and trading of financial instruments, and the management of transport (Heng, 2003).

E-Commerce is a part of e-business and its goal is to generate profit through the various set of activities based on buying and selling principles. E-commerce is strongly related to the information technologies and telecommunication technologies. The banking industry as a fast growing industry is facing the challenges of electronic commerce business. Although the ecommerce basics have been well known for

Copyright (c) 2011 Peterson Obara Magutu, Michael Mwangi, Richard Bitange Nyaoga, Gladys Monchari Ondimu, Margaret Kagu, Kipngeno Mutai, Henry Kilonzo and Peninah Nthenya. This is an open access article distributed under the Creative Commons Attribution License unported 3.0, which permits unrestricted use, distribution, andreproduction in any medium, provided that original work is properly cited. Contact author: Peterson Obara Magutu E-mail: magutumop@uonbi.ac.ke 
years, some adjustments according to the banking needs have been adopted. An efficient way to do e-business is to manage Web implementation of the assets that present and support entity's core business operations, including the software applications and databases in the information technology environment. Although a significant investment might be expected to cover the requirements of powerful, flexible and secure technology, there are many tools on the market supporting ebusiness technology fundamentals and products needed to build e-business solutions (Vedran Batos 2003).

E-commerce has improved business operations, the operations function is that part of the organization that is concerned with the management of the business process that produces the goods and services supplied to the customer. These processes of order fulfillment and delivery are the heart of every business as they are the means by which an organization satisfies its customers. An organization can be considered to have e-operations if it uses information technologies (ICT) in the management of its order fulfillment and delivery processes (Fraser and McDonald 2000).

Three primary processes are enhanced in ebusiness and they are; the production processes is the first which include procurement, ordering and replenishment of stocks; processing of payments; electronic links with suppliers; and production control processes, among others. The second is customer-focused processes, which include promotional and marketing efforts, selling over the Internet, processing of customers' purchase orders and payments, and customer support, among others. An internal management process, which is the third, includes employee services, training, internal information-sharing, video-conferencing, and recruiting. Generally electronic applications enhance information flow between production and sales forces to improve sales force productivity. Workgroup communications and electronic publishing of internal business information are likewise made more efficient (Wenninger, 2000).

\section{The Concept of E-Commerce}

E-commerce consists of buying and selling of products and services over electronic systems such as the internet and other computer networks (Mahadavan, 2000). Modern electronic commerce typically uses the World Wide Web at some point in the transactions lifecycle, although it can encompass a wide range of technologies such as e-mail. A small percentage of e-commerce is conducted entirely electronically for virtual items such as access to premium content on a website, but most e-commerce eventually involves physical items and their transportation in at least some way.

Today, it encompasses a wide range of business activities and processes, from e banking to off shore manufacturing to e-logistics. The ever growing dependence of modern industries on electronically enabled business processes gave impetus to the growth and development of supporting systems, including backend systems, applications and middleware (Chaudhury et al., 2002). Examples are broad band and fiber optic networks, supply chain management software, customer management software, inventory control systems and financial accounting software.

The emergence of e-commerce also significantly lowered barriers to entry in the selling of many types of goods; accordingly many home based proprietors are able to use the internet to sell goods. Often small sellers use online auction sites such as e-bay or sell via large corporate websites such as amazon.com, in order to take advantage of the exposure and set up convenience of such sites (Magutu et al, 2009).

\section{E-Commerce Services and Products}

E-commerce products and services are methods used by banking organizations to carry out their transactions without necessarily coming into physical contact with their clients. These services include Automatic Teller Machines (ATMs), Electronic Fund Transfer (ETF), mobile banking, online banking, Electronic Data Interchange (EDI) and telecommunication services.

Credit card is one of the few remarkable innovations introduced successfully by banks in the last five decades, and it is currently being used extensively in B2C electronic commerce. But it is an expensive means of payment for ecommerce and many on-line shoppers will prefer other forms of paying for their purchase (Long $2000)$. So will many on-line retailers who have to cough up set up and transaction costs and 2-3\% of every payment. Moreover credit cards are not suitable for person-to-person trade on the Internet. In short, e-commerce has created a demand for low cost facility for micro payments and flexible payment (Long 2000). New ways of on-line payments are appearing in the market, such as deduction from a pre-paid account, electronic billing services, direct transfer out of bank accounts.

There is a possibility for credit card companies and banks to act as information intermediaries. In such a construction, a bank customer downloads software from the bank that he knows and can trust. With the help of the 
software, he can browse without the target websites knowing his identity at all. When he decides to buy an article on-line, the software generates a new identity for him, with a fictitious name and e-mail address, a coded postal address, and a one-off credit card number. The new identity is sent, via the online merchant, back to the bank. The bank would then check the details of the transaction and approves the transaction. The post office receives a decoded address label and the coded name.

Trading in cyberspace has its risk. This is the sense of uncertainty associated with lack of relevant information that matters (Bodie and Merton 1998). There are interesting emergences in the new trading environment in cyberspace. For example, there is a demand for rating agencies whose main function is to monitor and grade, on a regular basis, the quality of goods and services, as well as to rate the ability of buyers and sellers to meet their commitment. The electronic market supports an efficient use of information dispersed among economic agents. It provides a concrete example of a rational economic order, as described by Hayek (1945). He argues that the economic problem of society is a problem of the utilization of knowledge not given to anyone in its totality. 'The peculiar character of the problem of a rational economic order is determined precisely by the fact that the knowledge of the circumstances of which we must make use never exists in concentrated or integrated form, but solely as the dispersed bits of incomplete and contradictory knowledge which all the separate individuals possess.

Besides the issues about quality, there is the related concern of fraud which is often expressed by on-line customers. From the seller's point of view, there is a new need for him to be guaranteed that the buyers would pay. Banks have entered the picture by being supportive party in on-line transactions. A buyer of a car (say) offered for sales on-line would get the quality guarantee from a rating agency. After striking the deal with the seller, he would deposit the money with the bank associated with the electronic market. As a participant against fraud technique, a bank would certify the identities of its own account holders and act on behalf of its account holders to verify the identities of account holders at other banks. Such intermediary role increases the security of the on-line business.

E-commerce provides a new avenue for a few of the biggest commercial banks with technological capabilities to offer other business firms the technology to conduct business-to-business ecommerce (Wenninger 2000). These big players are assuming the role of automating the entire information flow associated with the procurement and distribution of goods and services among B2B partners'. Being information based and related to financial transactions, these services are seen by banks as an extension of the cash management services they have been providing to large corporations.

Banks with technological know-how can offer their expertise to assist businesses to participate in e-commerce. In concrete terms, they can help smaller firms set up the infrastructure and payment capabilities to engage in e-commerce. A few banks are helping small businesses in coping with the negotiation of volume discounts from vendors and electronic procurement services (Wenninger 2000).

\section{E- Commerce Services and Products: Benefits and Challenges}

Some of the benefits that accrue to an organization from implementation of ecommerce are increased revenue since you will be able to reach more customers, improved customer satisfaction since services will be readily available and fast in their provision, cost reduction because it will not have to incur heavy wage bill, reduced space requirements and hence reduced rent or lease payments.

Other benefits include increased efficiency since automation enables you to do more with less input, increased level of output and employee satisfaction and motivation since they will not have to toil really hard. Larger market share through attraction of new customers and customer loyalty may be gained (Czerniawska and Potter, 2000).

In almost all instances, you cannot have any benefit without incurring cost or facing challenges. The following are the challenges that you are likely to face in the implementation of ecommerce. Your potential customers do not trust your site: The Internet allows mom-and-pop websites to look just as good -maybe even betterthan the websites of large corporations. All potential customers are well aware of this and they will be unimpressed by a sophisticated layout and a professional logo. Potential customers do not trust the site they have just arrived at, and it must be your conscious decision to do what it takes to make them change their minds (Mahadevan and Venkatesh, 2000).

Security concerns, the site may be attacked by hackers who may use the organization's website to defraud you existing and other potential customers. Cost of acquisition installation and maintenance is also another issue that requires the commitment of huge resources to acquire the 
system, to continuously update it and repair incase of break down. You also have to invest in employee training or alternatively hire qualified employees who are usually expensive.

Resistances by customers to adopt the new technology since most traditional customers are still shy of technology. They still don't want to deal with machines when carrying out their transactions instead they still want to deal with a physically present customer service employee; hence you may find that your system is not fully utilized (Summer, 1971).

The uptake of e-commerce is influenced by its potential to create business value and by awareness of its participants of the potential benefits (Magutu et al., 2009) A major reason for most companies, irrespective of size, to participate in business is to extract some benefit from it. E-commerce is no different. The benefits of e-commerce identified from the current literature are classified in two main categories tangible and intangible.

The tangible benefits are benefits that directly accrue to the organization and contribute directly to increase in revenue and profit. These include: Efficiency which is the ability of the business process to produce the same level of output using reduce resource output or to produce more output using the same level of input (Fraser et al. 2000; Lee 2001). Increased automation of processes where most of the operational activities which were done by people are carried out by machines without physical presence of people (Fraser et al. 2000).

E-commerce enables accessibility of markets that would have been otherwise inaccessible without automation. This is for example customers who wish to carry out transaction at night are taken care of by the use of ATMs. This process leads to transformation of traditional market chain (Fraser et al. 2000).

Retained and expanded customer base and acquisition of a niche market. By the use of internet and electronic fund transfer, banks are able to serve customers who are in places where they don't have branches (Fraser et al. 2000; Rahul, Biju and Abraham2001; Turban, et al, 2000).

Reduced operation costs. When people are replaced by machines in an organization, the amount of salary paid out is reduced and hence the operation cost decrease (Grover and Ramanlal, 2000; Kare-Silver, 1998). Intangible benefits are benefits that do not directly contribute to increase in revenue but may give goodwill and customer loyalty to the organization. They include, enhancing well-being and education of customers. By providing information to customers online, they are enabled to learn more about the organization and also how to carry out their transaction effectively and efficiently at reduced time and cost (Kalakota and Whinston, 1997; Lee 2001).

Improving consumer loyalty, when quality services and products are provided, customers are likely to make repeatd purchase and relate themselves well with the organization (Lee 2001; Hoffman and Novak, 1999). Give organizations competitive advantage in that the organization that use automated business processes are able to provide products and services at reduced prices than their competitors. This enables them to beat their competitors and close out entry of new entries (Kalakota et al. 1999; Hoffman et al. 1999; Straub, 2000; Kare-Silver, 1998).

Offer convenient shopping to customers. Customers are enabled by e-commerce to carry out their transaction at any place in the world and at any time of the day that is convenient to their unique lifestyle. To extract benefits from ecommerce, it is important for businesses to overcome the e-commerce inhibitors and challenges. E-commerce challenges identified from the literature are classified as technological, managerial, and business related.

Technological challenges are related to the acquisition, installation and maintenance of the necessary hardware and software. These challenges are Security and Web site issues (Koved et al. 2001); the organizations data may face threats from hackers and data loss occasioned by things like viruses. Hackers may also proliferate bank system to transfer money from one account to another and this may make both the bank customers and the bank itself to lose huge sums of money. This may prove costly to the organization i.e. in their prevention Czerniawska \& Potter, 1998; Alexander, 1998).

Technology issues including costs, software and infrastructure; an e-commerce system requires great expenditure in monetary terms. You need to acquire the hardware, software both initial and maintenance e.t.c. (Hoffman et al. 1999; Abeyesekera et al. 1999; Rahul et al. 2001).

Others are managerial challenges and include people and organizational issues; the people in the organization may resist adoption of the new 
technology as they may fear that it would lead to loss of jobs. They may also be reluctant to adopt new methods as they may fear change. Another thing to consider is that, you may need to restructure the organization and this may be a challenge in it self (Hoffman et al. 1999; Feeny 2000).

Obtaining senior management backing: every major activity in the organization needs to have management support. A supporting management will provide the necessary resources. If the management does not support the e-commerce project, it means that the project will lack the necessary resources and is thus bound to fail. (Feeny 2000).

Business challenges include customer service where the bank will lose the personalized service that it offered its customers. When this personal feel is lost, customer loyalty may be reduced or entirely lost (Whinston et al. 1997; Alter, 1999; Lee 2001).Customers' old habits; customers may stick with the old habits and may not be ready to adopt change. They may even lack trust for the new technology and hence your e-commerce system may be under utilized (Schwartz, 1999).

Legal issues may arise from the adoption of ecommerce. The organization may be sued because of a loss suffered from the failure of their system. Again, the organization may find itself facing new kinds of legislations which are continuously being enacted by the governing bodies, in this case the CBK (Lawrence et al. 1998; de Souza \&Von Wiese 2000).

\section{Statement of the Problem}

The research intended to establish the benefits enjoyed and the challenges faced by commercial banks in Kenya in their provision of e-commerce products and services.

The early history of banking in the West can be read as a story of the evolution of banks in the process of meeting the needs of modern commerce. Banks in Europe began as money changers who specialized in accessing and valuing the coins used in claim some credit for their contribution to e-commerce. Commerce had existed as early as the division of labor ushered in by the agricultural revolution. But commerce then had not stimulated the emergence of the market centers (De Roover 1948; Lane and Muller 1985; Summer 1971). In the early 13th century, cities like Venice, Florence and Genoa bloomed and grew to become economic and cultural engines. These cities drove and expressed new aspirations and ways of thinking directed to material purposes; in the process they created new social behaviors. Venice was a great commercial centre, and it was here that banking for the first time separated itself from the changing of money (Roberts 1996). They evolved to become deposit banks, acting as custodians of their clients' money. This proved to be very useful to traders who gradually learned to trust the banks. With traders coming to accept book entry transfers as payment for their merchandise, banks acquired the role as payment intermediary between buyers and sellers. As long as the depositors could trust the banks, most of their money was laying idle there. This was soon discovered by the bankers. They realized that they could hold some reserves against deposits, and could lend out the rest against some collateral or invest in promising business ventures. "Banks began when men saw from experience that there was not sufficient money in specie for great commerce and great enterprise." (Summer 197.) With this new business activity, they carried out an additional role as financial intermediary between savers and investors/borrowers or become investors themselves. The second role allowed banks to provide liquidity in the economy. This has farreaching economic consequences, both in the form of economic benefits and risks.

The intellectual life in Italy at that time was fermenting and vigorous. Florence was the focus of the most intense and influential cultural activity in the whole of Europe. From 1350 to 1450, more scholars, artists, scientists, architects, and poets lived and worked in Italy than anywhere else in the western world. Many of them came from other countries to participate and contribute to that great unplanned historical phenomenon known later as the Renaissance. "Europe went, as it were, to school there." (Roberts 1996). Against this background of intellectual vitality, flourishing commerce brought with it a chain of institutional innovations. The bill of exchange appeared in the 13th century along with the first bankers. Limited liability was known in Florence in 1408, and marine insurance was available before that (Roberts 1996). Double entry bookkeeping evolved to meet the needs of merchants (Bodie and Merton 1998). By 1500, Italians had invented new credit instruments for banks in the form that we know it. The task was left to modern commerce, i.e. the financing of international commerce. The Amsterdam stock exchange was established in early $17^{\text {th }}$ century (Braudel 1968).

The $19^{\text {th }}$ century saw the regular market being replaced by continuous trading, purchase by sample, the rise of shop keeping, and replacement of fairs by produce exchanges or bourses. The contribution of traders to the 
establishment of banks is well documented (Summer 1971; Clough and Cole 1968). In Europe, banks were established in centers of great foreign commerce such as Venice, Amsterdam, Hamburg and Nuremberg. It was "merchant capital which created markets, financed manufactures, floated the American colonial economies and launched banking and insurance." (Grassby 1970) Even today, we still see the role of traders as modest providers of credit to peasants and farmers in developing countries. In emerging economies the activities of traders promote not only the more efficient deployment of available resources, but also the growth of resources (Bauer 1991).

Although a lot of research work has been done on the prospects and challenges of information technology in firms in Kenya, most of them are broad based and only a few are on e-commerce services in the banking industry. Muganda (2001) investigated business values of ecommerce amongst selected firms in Kenya. From his study he sought to investigate the business value of e- commerce amongst firms in Kenya. According to his summary, most of firms on average agree that e- commerce value result in organizational improvement, transformation and redefinition. Kiyeng' (2003) reviewed broadly the business effects and challenges faced by companies which have adopted e-commerce in Kenya. From his study, he was to examine the services offered by e- sokoni to its members and evaluate the impact and challenges faced by esokoni member companies as well as e- sokoni as an e- market. Muyoyo (2004) investigated factors influencing the adoption and implementation of e-business technologies in companies quoted in NSE and his result showed dominance of basic ebusiness activities, suggesting considerable scope for future diffusion of $\mathrm{e}$ - business technology in large quoted firms that already use interactive web based information systems. Ojung'a (2005) investigated e-commerce services in commercial Banks in Kenya. His study gave various outputs and some of them included the extend to bank to bank e- commerce service utilization, extend to bank to customer electronic payment methods and extend of usage of electronic payment methods. Magutu et al., (2009) modeled the effects of E-Commerce adoption on Business Process Management: Case Study of Commercial Banks in Kenya.

The aim of the paper was to show that ecommerce has transformed banking systems in a radical way. There are three aspects in which ecommerce has affected banking. First, banks use the technology and business practice of ecommerce to market their services and products to their customers. Second, e-commerce provides business opportunity for banks to offer new products and services to serve the ever changing needs of e-commerce. Third, the new business environment associated with ecommerce holds potential for institutional innovations in banking, which can help to lay a sounder foundation for the international financial system.

The specific objectives of the study were: to establish the extent to which E-commerce services have been utilized in the Kenyan banking sector; to investigate whether Ecommerce adoption results in organizational transformation; to identify the benefits derived by banks from implementation of e-commerce; and lastly, to establish the challenges faced by banks in implementing e-commerce products and services.

\section{Research Strategy}

The guiding principles here were the objectives of the study. A survey research design sought information from various banks in Kenya to examine and analyze the benefits and challenges they face in implementing e-commerce products and services. The population of the study consisted of 44 commercial banks that are currently operating in Kenya (See appendix II). The target population was at least two members of the management team with representations in the following dimensions; locally incorporated banks, banks incorporated elsewhere but operating in Kenya, banks in which the government has some share holding and also based on size. Thus 100 questionnaires were dispatched. Purposeful sampling was employed. The choice of the sampling technique used was due to the fact that the chosen respondents had the information sought for.

This study relied on both primary and secondary data. The questionnaire (See appendix I) was piloted on 10 banks prior to data collection. This was necessary in order to identify any ambiguous and unclear questions and any questions that were not clear to the respondents were clarified. The questionnaires were then submitted to the participating firms after the pilot test in order to get the data and information required, which was administered using e-mail and drop-pick-later method. Follow up was done by telephone. Questionnaires were used because we perceived that it would save on our time and it would be flexible with the respondents' times who mostly have fixed schedules. The questions were structured in such a way that for fixed response questions were rated against five points scale, from extremely significant (5) to not significant(1).

Room was provided for personal responses not captured in the fixed response- questions. The questionnaire was divided into five parts. Part A 
captured organizational data, part B captured the applications of e-commerce, part $\mathrm{C}$ was for reasons for adoption of e-commerce, part D was for benefits derived from e-commerce and part $\mathrm{E}$ captured the challenges faced by the commercial banks in the adoption of e-commerce.

The data from respondents was analyzed using descriptive statistics such as means, percentages and tables. Together with correlation analysis, factor analysis was done to establish the relationships among the study variables. In particular, factor analysis procedure was used to measure and establish benefits and challenges that commercial banks face in implementing ecommerce products and services. This method was necessary to reduce a set of several difficult to interpret correlated variables to few conceptually meaningful relatively independent factors which could be easily interpreted. This technique was applied to summarize 32 latent variables or sub-variables representing dominant benefits and challenges. To make interpretation easier, a linear transformation on the factor solution, varimax rotation was done, which gave fewer components (factors) that are uncorrelated with one another. SPSS (Statistical Package for Social Scientists) was used to analyze the data.

\section{Data Analysis and Findings}

Data was collected from hundred (100) managers from the commercial banks in Kenya. Of the 100 managers and heads of departments sampled, 70 responded, a reasonably high response rate of 70 percent.

\section{Adoption of E-Commerce}

There are a number of e-commerce products and services that banks can offer. They can take various forms, either B2B, B2C, C2B etc.

The respondents were asked to indicate the extent to which they have utilized the bank to bank e- commerce service. From the 5 point scale used, the table below gives the result.

Table 4.1 B2B E-Commerce Services

\begin{tabular}{|l|l|l|}
\hline B2B e-Commerce Services & Mean & Std. Deviation \\
\hline EFT electronic payment bank to bank & 4.14 & 1.215 \\
\hline EFT via EDI & 3.86 & 1.464 \\
\hline Automated clearing through EFT & 3.71 & 1.704 \\
\hline $\begin{array}{l}\text { Settlement of payment on a gross basis in } \\
\text { real time }\end{array}$ & 3.57 & .787 \\
\hline $\begin{array}{l}\text { Truncation and cheque imaging } \\
\text { transmission }\end{array}$ & 2.43 & 1.134 \\
\hline $\begin{array}{l}\text { Settlement of Government Securities } \\
\text { electronically }\end{array}$ & 2.14 & 1.574 \\
\hline
\end{tabular}


Since a score of one represents low level of usage of the services while a score of five represented the highest level of usage, to a great extent B2B ecommerce services key to banks are: EFT electronic payment from bank to bank, EFT via EDI, automated clearing through EFT and the settlement of payment on a gross basis in real time. Truncation and cheque imaging transmission and Settlement of Government Securities electronically have not gained prominence with banks. This is because of the developing nature of economy and little investment in e-government.
The respondents were further asked to indicate the extent to which they have utilized the bank to customer e- commerce service. From the 5point scale used, the table below gives the result.

From the results in table 4.2 below, internet banking, EFT, mobile and office banking are the most commonly used B2C e-commerce services by customers with a mean greater than 4 , while Tele-banking and branch banking are moderately used. Home banking is the least popular B2C ecommerce.

Table 4.2 B2C E-Commerce

\begin{tabular}{|c|c|c|}
\hline B2C e-commerce Services & Mean & $\begin{array}{c}\text { Std. } \\
\text { Deviation }\end{array}$ \\
\hline $\begin{array}{c}\text { Internet banking- direct } \\
\text { access to your account }\end{array}$ & 4.43 & .535 \\
\hline EFT & 4.29 & 1.496 \\
\hline Office banking & 4.14 & 1.464 \\
\hline Mobile Banking & 4.00 & 1.000 \\
\hline Branch banking & 3.86 & 1.345 \\
\hline Tele-banking & 3.67 & 1.374 \\
\hline Home banking & 2.71 & 1.604 \\
\hline
\end{tabular}

\section{Reasons for Adoption of E-Commerce}

Banks have various reasons for adoption of ecommerce. The table 4.3 below gives details. The main reason for the adoption of e-commerce by banks was to improve customer service, to cut down on operational costs, to keep up with industry trend and lastly to respond to customers' demands. Other reasons include expanding bank market share, to increase bank profitability, to create customers awareness of ecommerce services, to increase geographical reach, profitability and as a response to customers awareness on e-commerce services, to increase customer awareness on bank Products and to extend bank geographical reach. The most insignificant reason for their adoption was compliance with regulations.

Table 4.3 Reasons for Adoption of E-Commerce

\begin{tabular}{|l|l|l|}
\hline $\begin{array}{l}\text { Reasons for e-Commerce } \\
\text { Adoption }\end{array}$ & Mean & Std. Deviation \\
\hline Improve Customer Service & 4.71 & .488 \\
\hline Cut down operational costs & 4.71 & .488 \\
\hline Keep up with industry Trend & 4.43 & 1.134 \\
\hline Response to customers' demands & 4.14 & 1.069 \\
\hline Expand bank market share & 3.86 & .900 \\
\hline Increase bank profitability & 3.86 & 1.345 \\
\hline $\begin{array}{l}\text { Response to Customers awareness } \\
\text { of e-commerce services }\end{array}$ & 3.86 & 1.069 \\
\hline $\begin{array}{l}\text { Increase customer awareness on } \\
\text { bank Products }\end{array}$ & 3.71 & .951 \\
\hline Extend bank geographical Reach & 3.14 & 1.069 \\
\hline Compliance with regulations & 2.14 & 1.345 \\
\hline
\end{tabular}




\section{Benefits Derived from E-Commerce}

There are various benefits that have been derived by banks in Kenya from the adoption of e-commerce. The respondents were asked to
Indicate the extent to which their banks have benefited from the adoption of e-commerce services and products and the responses are as in table 4.4. below.

Table 4.4 E-Commerce Benefits (Descriptive Statistics)

\begin{tabular}{|l|l|l|}
\hline e-Commerce Benefits & Mean & Std. Deviation \\
\hline Quickened transaction processing & 4.67 & .51640 \\
\hline Provided 24/7 availability of your services & 4.50 & .54772 \\
\hline Increased customer convenience & 4.50 & 1.22474 \\
\hline Increased customer loyalty & 4.17 & .40825 \\
\hline Enabled banks to collect customer data & 4.17 & 1.16905 \\
\hline Increased bank turnover and profitability & 4.17 & 1.16905 \\
\hline Reduced bank operating overheads & 4.00 & 1.09545 \\
\hline $\begin{array}{l}\text { Provided customers with valuable information about } \\
\text { bank business }\end{array}$ & 3.83 & .98319 \\
\hline Reduced phone costs and paper work & 3.8333 & 1.16905 \\
\hline Increased productivity of your staff & 3.8333 & 1.16905 \\
\hline Reduced marketing and advertising costs & 3.5000 & .83666 \\
\hline Expanded customer base & 3.3333 & 1.50555 \\
\hline $\begin{array}{l}\text { Increased customization of products online by you } \\
\text { customer }\end{array}$ & 3.3333 & 1.21106 \\
\hline $\begin{array}{l}\text { Increased visibility of your bank through search } \\
\text { engine marketing }\end{array}$ & 3.1667 & 1.32916 \\
\hline Enabled you to reach a narrow market niche & 3.1667 & 1.32916 \\
\hline Personalized service & 3.1667 & 1.72240 \\
\hline High Quality customer service & 1.32916 \\
\hline Expanded geographical reach & 1.54919 \\
\hline
\end{tabular}


The major benefits derived from e-commerce are: quickened transaction processing, provided $24 / 7$ availability of your services, increased customer convenience, increased customer loyalty, enabled banks to collect customer data, increased bank turnover and profitability, and lastly reduced bank operating overheads. Other benefits include: e-commerce has provided customers with valuable information about bank business, reduced phone costs and paper work, increased productivity of bank staff and lastly reduced marketing and advertising costs.

From the scree plot, only 3 factors are significant: quickened transaction processing, provided $24 / 7$ availability of your services, increased customer convenience, and increased customer loyalty.

The latent benefits that have been realized by banks with the adoption of ecommerce services and products include: expanded customer base, increased customization of products online by bank customers, increased visibility of your bank through search engine marketing, enabled you to reach a narrow market niche, personalized service, high quality customer service and expanded geographical reach. This is an indication that the banks have not fully realized the benefits of e-commerce, since some of the key reasons for the adoption of e-commerce have not been realized as benefits.

Table 4.5 Table 4.4 E-Commerce Benefits (Component Matrix)

\begin{tabular}{|c|c|c|c|}
\hline \multirow[b]{2}{*}{ e-Commerce Benefits } & \multicolumn{3}{|c|}{ Component } \\
\hline & 1 & 2 & 3 \\
\hline Expanded geographical reach & $* 828$ & -.122 & .129 \\
\hline Expanded customer base & $* 958$ & -.085 & .238 \\
\hline $\begin{array}{l}\text { Increased visibility of your bank } \\
\text { through search engine marketing }\end{array}$ & $* 905$ & .404 & .117 \\
\hline $\begin{array}{l}\text { Provided customers with valuable } \\
\text { information about your business }\end{array}$ & $* 790$ & -.501 & -.288 \\
\hline $\begin{array}{l}\text { Provided } 24 / 7 \text { availability of your } \\
\text { services }\end{array}$ & $* 696$ & .333 & -.635 \\
\hline increased customer loyalty & .302 & -.205 & *919 \\
\hline $\begin{array}{l}\text { Reduced marketing and advertising } \\
\text { costs }\end{array}$ & $* 638$ & -.712 & -.003 \\
\hline Enabled you to collect customer data & .658 & *738 & -.127 \\
\hline $\begin{array}{l}\text { Enabled you to reach a narrow market } \\
\text { niche }\end{array}$ & $* 992$ & -.034 & -.013 \\
\hline Increased customer convenience & .475 & $* 833$ & .244 \\
\hline $\begin{array}{l}\begin{array}{l}\text { Increased your turnover } \\
\text { profitability }\end{array} \\
\end{array}$ & .290 & $* 785$ & .496 \\
\hline Reduced your operating overheads & $* 821$ & -.526 & .084 \\
\hline Quickened transaction processing & .976 & .191 & .053 \\
\hline Reduced phone costs and paper work & $* 889$ & .041 & -.216 \\
\hline $\begin{array}{l}\text { Increased customization of products } \\
\text { online by you customer }\end{array}$ & $* 928$ & -.318 & -.096 \\
\hline Increased productivity of your staff & $* 876$ & -.098 & .162 \\
\hline Personalized service & .827 & -.210 & .292 \\
\hline High Quality customer service & $* 691$ & .267 & -.628 \\
\hline
\end{tabular}

Extraction Method: Principal Component Analysis.a 3 components extracted.

From the analysis, we were able to extract 3 factors.

- Factor 1 (bank benefits) incorporated all benefits that accrued mainly to the bank.

- Factor 2 (customer benefits) incorporated the benefits that are being derived by the customers from e-commerce.
- Factor 3 (Customer loyalty) symbolized that ecommerce that made customers to be loyal.

\section{Challenges Faced in Adoption E-Commerce}

The implementation of e-commerce could not come without challenges. The tables below give an explanation of the challenges that have been faced. 
Table 4.5 Challenges Faced in Adoption E-Commerce (Descriptive Statistics)

\begin{tabular}{|c|c|c|}
\hline Challenges & Mean & Std. Deviation \\
\hline Electronic signatures & 4.0000 & 1.09545 \\
\hline Slow internet speed & 3.6667 & 1.36626 \\
\hline Security of payments & 3.5000 & 1.64317 \\
\hline e-invoice & 3.3333 & 1.63299 \\
\hline $\begin{array}{l}\text { Privacy of personal } \\
\text { data }\end{array}$ & 3.3333 & 1.21106 \\
\hline $\begin{array}{l}\text { Internet connection } \\
\text { failure }\end{array}$ & 3.3333 & 1.50555 \\
\hline Data protection & 3.1667 & 2.04124 \\
\hline Online marketing & 3.1667 & 1.32916 \\
\hline $\begin{array}{l}\text { Validity of a contract } \\
\text { concluded by electronic } \\
\text { means }\end{array}$ & 2.8333 & 1.32916 \\
\hline Security breach/fraud & 2.8333 & .98319 \\
\hline Threat from viruses & 2.6667 & 1.03280 \\
\hline $\begin{array}{l}\text { Lack of personal } \\
\text { contact with customers }\end{array}$ & 2.6667 & 1.21106 \\
\hline Taxation/customs & 2.3333 & .81650 \\
\hline Data retention & 2.3333 & .81650 \\
\hline $\begin{array}{l}\text { Customer difficulty in } \\
\text { using finding your } \\
\text { website }\end{array}$ & 2.3333 & .81650 \\
\hline $\begin{array}{l}\text { Running and } \\
\text { maintenance more } \\
\text { costly than expected }\end{array}$ & 2.3333 & 1.03280 \\
\hline Lack of user Support & 2.3333 & .81650 \\
\hline
\end{tabular}

From the research data, the greatest challenge was the use of signatures in electronic documents. Other major challenges of ecommerce in bank operations include: slow internet speed, security of payments, e-invoicing, privacy of personal data, internet connection failure, data protection and online marketing. Several challenges were ranked least based on their magnitude: taxation, data retention, customer difficulty in using and finding the websites and lack of user support. 
Table 4.5 Challenges Faced in Adoption E-Commerce (Component Matrix-a)

\begin{tabular}{|l|l|l|l|}
\hline \multirow{2}{*}{ Challenges } & Component & \multicolumn{2}{l|}{} \\
\cline { 2 - 4 } & 1 & 2 & 3 \\
\hline electronic signatures & .147 & $.856^{*}$ & .452 \\
\hline e-invoice & -.042 & .664 & $.742^{*}$ \\
\hline Taxation/customs & $.972^{*}$ & -.198 & .095 \\
\hline security of payments & .321 & $.868^{*}$ & -.142 \\
\hline Data protection & $.621^{*}$ & .598 & -.396 \\
\hline Data retention & $.972^{*}$ & -.198 & .095 \\
\hline $\begin{array}{l}\text { Validity of a contract concluded by electronic } \\
\text { means }\end{array}$ & $.280^{*}$ & -.719 & -.301 \\
\hline Privacy of personal data & $.822^{*}$ & .504 & -.236 \\
\hline Online marketing & .603 & -.183 & $.691^{*}$ \\
\hline Slow internet speed & .297 & $.925^{*}$ & .007 \\
\hline Threat from viruses & $.742^{*}$ & .036 & -.502 \\
\hline Security breach/fraud & $.637^{*}$ & -.231 & -.689 \\
\hline Internet connection failure & .398 & $.839^{*}$ & -.260 \\
\hline $\begin{array}{l}\text { Customer difficulty in using finding your } \\
\text { website }\end{array}$ & $.972^{*}$ & -.198 & .095 \\
\hline $\begin{array}{l}\text { Running and maintenance more costly than } \\
\text { expected }\end{array}$ & $.664^{*}$ & -.411 & .599 \\
\hline Lack of user Support & $.972^{*}$ & -.198 & .095 \\
\hline Lack of personal contact with customers & $.882^{*}$ & -.335 & .297 \\
\hline
\end{tabular}

Extraction Method: Principal Component Analysis. a 3 components extracted.

From the analysis and results in table 4.6 the factors that were derived are 3. Factor 1(data challenge) included data retention, data protection, lack of user support, and lack of personal contact with customers. Factor 2(Security) entails security of payments and electronic signatures. Factor 3 (e-services) includes e-invoice and online marketing.

\section{Summary and Conclusions}

In line with the general objectives of the study, the following conclusions were arrived at which were further used to model the operation strategies used in solid waste management.

\section{Conclusions}

Based on the results from data analysis, findings and discussions above, one can safely conclude the following:

- First, commercial banks appreciate the ecommerce as evidenced by its wide adoption. Although most commercial banks have introduced e-commerce services and products, it is not yet very popular with most of their customers. This could be because the majority of the customers who the banks serve, lack enough access to information technology infrastructure, knowledge and skills. The banks should popularize the use of e-commerce by educating their customers about their use and the advantages that come with it.

- Secondly, most banks implement the ecommerce facilities for the sole purpose of meeting the organization's interests like profitability and cost reduction. They should instead put into consideration other external factors like reducing environmental pollution by not using paper. .There are no legal requirements that commercial banks use ecommerce. The government can introduce such regulation in order to improve the efficiency of the banking industry as well as to reduce the banking costs incurred by the people.

- Thirdly, although the benefits of implementation of e-commerce are recommendable, the distribution of such benefits should be put into consideration. This is, for example, people who cannot access 
internet services can be reached out by improving on easily accessible and affordable facilities like mobile banking.

- Lastly, although most of the challenges we came across are inherent, most of them can be reduced. E-commerce in banks is mainly hampered by illegal access and use of restricted information. Commercial banks indicate that internet hackers and computer viruses are the main threats and also highlight that they spend significant proportion of funds on these factors.

\section{Limitations and Suggestion for Further Research}

There was time and financial constraint in carrying out the research. The managers were actually too busy and reluctant to participate in the research and had to be really convinced to answer. Some respondents were biased since they feared disclosing the weaknesses of their banks.

This study focused on the e-commerce products and services adopted by commercial banks and the benefits and challenges they face in adopting these services. Further studies can be focused on the perceptions of customers towards the e-commerce services offered by the banks. It will also determine the benefits derived and challenges faced by customers who use such services.

\section{Acknowledgement}

During the trying moments of conducting this study and its subsequent compilation, which was researched and written over a period, many developments took place. Some several key people and institutions therefore need to be acknowledged for their professional generosity and input, considering the time this research has taken to come to fruition. Firstly, we wish to acknowledge and thank, the four B.Com students, now recognized as co-authors for their effort to collect data as research assistants by then. Alfred Karwega, whose incisive reading and constructive critiques of the paper in progress have been invaluable. Although not directly involved, Prof Mbeche, also needs a mention for his generosity to read and comment on various drafts at pivotal times throughout the formation of the Research paper. We also acknowledge the commercial banks in Kenya (especially, the IT managers) and all those other people who graciously gave their time to be interviewed/fill the research instrument.

\section{References}

Alexander (1998) ITU Electronic Commerce for Developing Countries (EC-DC).

Alter, S. (999) "Shopping.com: When Ecommerce isn't a Bargain", Communications of the Association for Information Systems, Volume 2, Article 22.

Bato, V. (2003) Application of E-Commerce in Banking Industry.

Bauer, P (1991) "the development frontier: essays in applied economics", Cambridge, MA: Harvard University Press.

Bodie, Z and Merton, R C (1998) Finance London: Prentice-Hall

Chaudhury, Abijit; Jean-Pierre Kuilboer (2001). e-Business and e-Commerce Infrastructure. McGraw-Hill.

Czerniawska, F. and Potter, G. (1998) Business in a Virtual World: Exploiting Information for Competitive Advantage.

De Souza, N. and I. von Wiese (2000). "European Union: EU adopts directive on ecommerce". International Financial Law ReviewVol 19(7): pp. 61-62.

Feeny, D. (2000). "The CEO and the CIO in the Information Age". Moving to E Business. L. Wilcocks and C. Sauer. London, Random House: pp. 168-187.

Fraser, J., N. Fraser and F. McDonald (2000). "The strategic challenge of electronic commerce", Supply Chain

Grassby, R (1970) English merchant capitalism in the late seventeenth century Past \& Present, vol. 46, p.87-107.

Grover, V., and Ramanlal, P. (2000) "Playing the E-commerce Game”, Business and Economics Review;

Hayek F.A. (1945) "The use of knowledge in society", American Economic Review, vol. 35, no. 4, (Sept), p.519-530.

Heng, M S H (2003) Understanding e-commerce from a historical perspective, Communications of the AIS, volume 12, July, p.104-118.

Hoffman, Donna. L. and Novak, Thomas. P. (1997), "A New Marketing paradigm for Electronic Commerce", The Information Society, Vol. 13, No. 1, pp. 43-54. 
Wenninger, J. \& Choi, S Y et al (1997) The Emerging Role of Banks in E-Commerce The economics of electronic commerce Indianapolis: MacmillanJoze Kuzic, Julie Fisher, Angela.

Scollary(2002) Electronic Commerce Benefits, Challenges and Success Factors in the Australian Banking and Finance Industry Kalakota.

Kalakota, Ravi. \& Whinston, A. (1997) "Electronic Commerce, a Manager's Guide". Addison-Wesley: Reading.

Kare - Silver, M., 1998, "E shock - The Electronic Shopping Revolution: Strategies for Retailers and Manufacturers", MacMilan Press LTD.

Kiyeng' Philip (2003) A Survey on the Impact and Challenges of business E-commerce in Kenya: A Case Study of Sokoni Koved, Larry. CVIEW: A Real-Time Interactive Conferencing System. IBM Research Division, Research Report RC16138, Yorktown Heights, NY. September 1990.

Lawrence, E et al (1998) Internet commerce New York: Wiley

Lawrence, E., Corbitt, B., Tidwell, A., Fisher, J., and Lawrence, J., 1998, "Internet Commerce: Digital Models for Business", John Wiley \& Sons, Brisbane.

Lee, C.-S. (2001). "An analytical framework for evaluating e-commerce business models and strategies", Internet Research: Electronic Networking Applications and Policy. 11(4): pp. 349-359.

Liao, Z., and Tow, M. (2001) "Internet- based Eshopping and Consumer Attitudes: An Empirical Study", Information and Management, Amsterdam, Vol 38, pp. 299.

Long 2000: Terry Pratchetts ScheibenweltQuizbuch (The Unseen University Challenge); München (Germany), Goldmann, paperback translation ISBN 3442445140

Magutu O. Peterson, Richard O. N, and Haron M,. 2009, Modeling the Effects of E-Commerce Adoption On Business Process Management: Case Study of Commercial Banks in Kenya: Communications of the IBIMA. Vol 8, 2009 ISSN: 1943-7765 pg 175.
Mahadavan B. 2000. Business models for Internet-based e-commerce. California Management Review Vol 42(4): p55-69.

Mahadevan, B. and Venkatesh, N.S. (2000). "A framework for building online trust in business to business E Commerce: Issues \& Challenges".

Muganda Nixon (2000) An investigation of the business value of E-commerce: The case of selected firms in Kenya.

Ojung'a Samuel (2005) A survey of Ecommerce Services in Banks in Kenya.

Rahul, D., M. Biju and D. Abraham (2001). "Critical constructs for analysing e-business: investment, user experience and revenue models". Logistics Information Management 14(1/2): pp. 137 - 148.

Raymond de Roover Lane and Muller (1985) Money, Banking and Credit in Mediaeval Bruges Italian Merchant-Bankers Lombards and Money-Changers: A Study in the Origins of Banking A history of money.

Roberts, J M (1996) A history o f Europe Oxford: Helicon

Schwartz, E. (1999) "Digital Darwinism: 7 Breakthrough Business Strategies for Surviving in the Cutthroat Web Economy", Broadway Books, New York.

Graham, S, W. (ed.) (1971) A history of banking in all the leading nations, volume 1. New York: Kelley Publishers.

Turban E, Lee J, King D H, Chunget M (2000). Electronic commerce: a managerial perspective. Prentice Hall, Upper Saddle River, NJ.

Zwass, V. (1996) Electronic Commerce and Organizational Innovation: Aspects and Opportunities.

Wenninger, J (2000) The emerging role of banks in e-commerce Current Issues in Economics and Finance, vol.6, no.3, p.1-6.

Whilstojn ,Kalkota (1996) Frontiers of ECommerce.

Chou, Y., Lee, C., and Chung, J. (2002) Understanding $\mathrm{m}$-commerce payment systems through the analytic hierarchy process. 


\section{APPENDIX I: QUESTIONNAIRE}

\section{PART A: ORGANISATIONAL DATA}

1. Name (optional)

2. Level of education

3. Designation

4. Name of the bank

5. Year of incorporation

6. Please tick the category that best describes your bank a) Foreign owned and not locally incorporated [ ]

b) Foreign owned but locally incorporated [ ]

c) With government participation [ ]

d) Wholly locally owned [ ]

\section{PART B: APPLICATIONS OF E-COMMERCE}

7. For each of the following bank -to- bank ecommerce services, indicate the extent to which it is applicable to your bank. Use a five point measurement scale as follows.

a)Settlement of payment on a gross basis in realtime. [1] [2] [3] [4] [5]

b) Settlement of government securities electronically [1] [2] [3] [4] [5]

c) EFT electronic payment bank to bank [1] [2] [3] [4] [5]

d) Automated clearing through EFT

$$
\text { [1] [2 ] [3] [4] [5] }
$$

$1=$ not applicable at all, $2=$ least applicable, 3=moderately applicable, 4= largely applicable, $5=$ applied to a great extent.

e)Truncation and cheque imaging transmission [1] [2 ] [3 ] [4] [5]

f) Electronic Funds Transfer via Electronic Data Interchange[1] [2 ] [3 ] [4] [5]

8. What other bank to bank e-services does your bank offer?

9. For each of the following bank- to- customer ecommerce services, indicate the extent to which it is applicable to your bank.

Use the 5 point measurement scale used above.

\begin{tabular}{|l|l|l|l|l|l|}
\hline FACTORS & 5 & 4 & 3 & 2 & 1 \\
\hline $\begin{array}{l}\text { Internet banking } \\
\text { - direct access to } \\
\text { account }\end{array}$ & & & & & \\
\hline Office banking & & & & & \\
\hline Home banking & & & & & \\
\hline Tele banking & & & & & \\
\hline Branch banking & & & & & \\
\hline Mobile banking & & & & & \\
\hline $\begin{array}{l}\text { Electronic funds } \\
\text { transfer (EFT) }\end{array}$ & & & & & \\
\hline
\end{tabular}

10. What other bank to customer e-commerce services does your bank offer? 


\section{PART C: REASONS FOR ADOPTION OF E-COMMERCE}

11. To what extent did the following factors influence adoption of e- commerce services in your bank?
Where $1=$ Very great extent; $2=$ Great extent; $3=$ Do not know; $2=$ Small extent; and $1=$ Very small extent

\begin{tabular}{|c|c|c|c|c|c|}
\hline FACTORS & 5 & 4 & 3 & 2 & 1 \\
\hline Improve customer service & & & & & \\
\hline Cut down on operational costs & & & & & \\
\hline $\begin{array}{l}\text { Increase customer awareness } \\
\text { on bank products }\end{array}$ & & & & & \\
\hline $\begin{array}{l}\text { Extend bank } \text { geographical } \\
\text { reach }\end{array}$ & & & & & \\
\hline Expand bank market share & & & & & \\
\hline Increase banks' profitability & & & & & \\
\hline Keep up with industry trend & & & & & \\
\hline Compliance with regulations & & & & & \\
\hline $\begin{array}{lll}\begin{array}{l}\text { Response } \\
\text { demands }\end{array} & \text { to } & \text { customers' } \\
\end{array}$ & & & & & \\
\hline $\begin{array}{lcc}\text { Response } & \text { to } & \text { customers' } \\
\text { awareness of } & \text { - } & \text { commerce } \\
\text { services } & & \end{array}$ & & & & & \\
\hline
\end{tabular}

Are there any other reasons? Please specify. 
PART D: BENEFITS DERIVED FROM E- COMMERCE.

12. To what extent has your organization derived the following benefits from the implementation of e-commerce facilities?
Where 1 = Very great extent; 2 = Great extent; 3 = Do not know; 2 = Small extent; and 1 = Very small extent

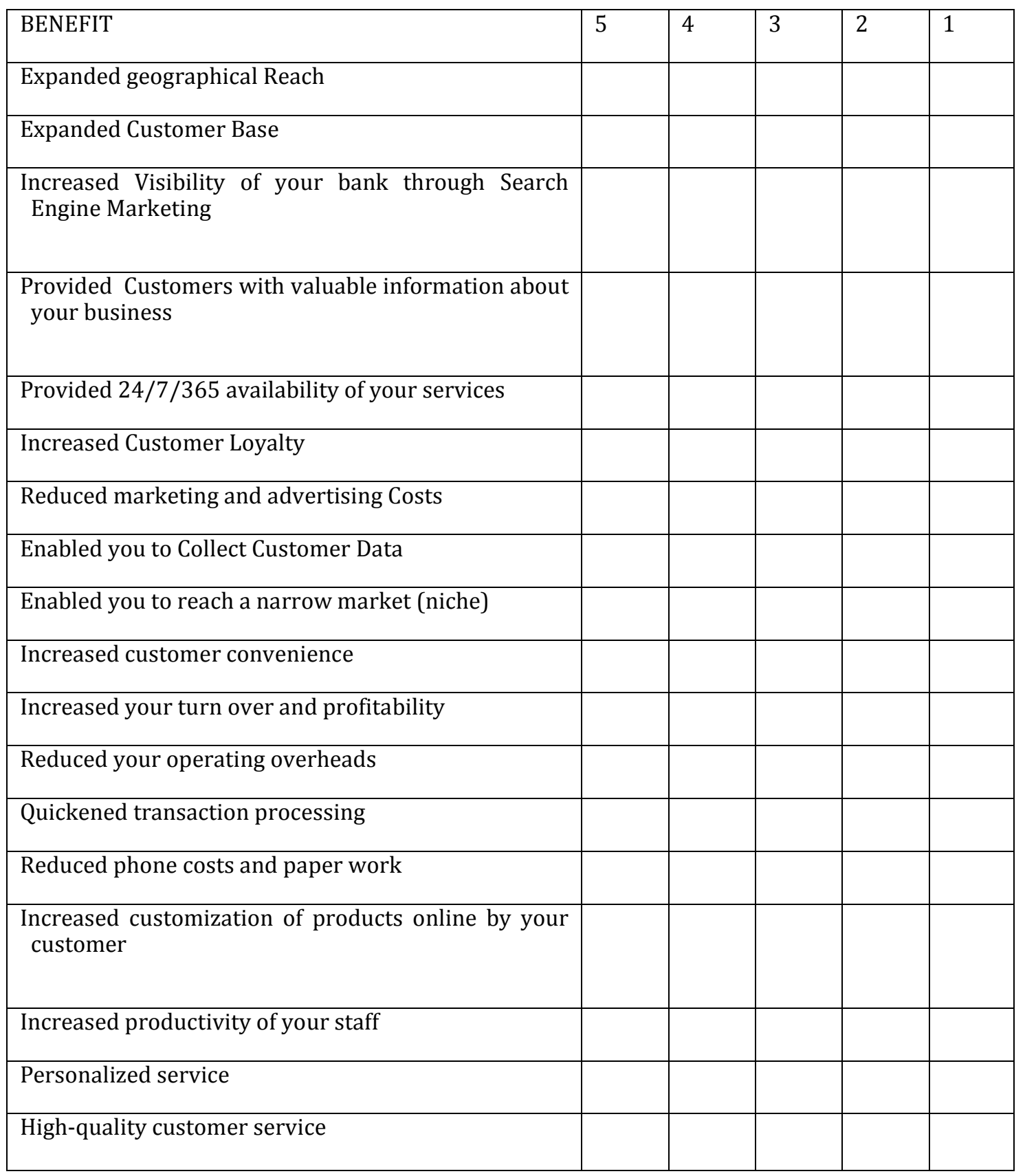

13. What are the other benefits your organization may have derived from implementing e- commerce facilities? 


\section{PART E: CHALLENGES FACED IN ADOPTION OF E COMMERCE}

14. To what extent have the following challenges affected your organization since the implementation of e-commerce facilities? (tick where appropriate)
Where 1 = Very great extent; 2 = Great extent; 3 = Do not know; 2 = Small extent; and $1=$ Very small extent

\begin{tabular}{|c|c|c|c|c|c|}
\hline CHALLENGE & 5 & 4 & 3 & 2 & 1 \\
\hline Electronic signatures & & & & & \\
\hline E invoice & & & & & \\
\hline Taxation/customs & & & & & \\
\hline Security of payment & & & & & \\
\hline Data protection & & & & & \\
\hline Data retention & & & & & \\
\hline $\begin{array}{l}\text { Validity of a contract concluded by } \\
\text { electronic means }\end{array}$ & & & & & \\
\hline Privacy of personal data & & & & & \\
\hline Online marketing & & & & & \\
\hline Slow internet Speed & & & & & \\
\hline Threat from Viruses & & & & & \\
\hline Security breach / fraud & & & & & \\
\hline Internet connection failures & & & & & \\
\hline $\begin{array}{l}\text { Customer difficulty in using / finding } \\
\text { your website }\end{array}$ & & & & & \\
\hline $\begin{array}{l}\text { Running and maintenance more costly } \\
\text { than expected }\end{array}$ & & & & & \\
\hline Lack of user support & & & & & \\
\hline Lack of personal contact with customers & & & & & \\
\hline
\end{tabular}

15. What are the challenges faced by your organization in implementing e commerce facilities?
16. Please give any other comment that you may deem useful for this exercise? 
The following are the commercial banks which have been operating in Kenya lately. Most of them have their head offices in Nairobi.

\section{Foreign Banks}
1) Bank of Africa, Nairobi
2) Bank of India, Nairobi
3) Citi bank, Nairobi
4) Habib Bank, Nairobi
5) Habib Bank A.G Zurich, Nairobi

\section{Foreign Owned but Locally Incorporated Banks}
1) Barclays Bank of Kenya, Nairobi
2) Stanbic Bank, Nairobi
3) Standard Chartered Bank, Nairobi
4) Diamond Trust Bank, Nairobi
5) Bank of Baroda, Nairobi

\section{Banks with Government Participation}
1. Stanbic Bank, Nairobi
2. Development Bank, Nairobi
3. Consolidated Bank Of Kenya Ltd4
4. Industrial Development Bank, Nairobi
5. Kenya Commercial Bank, Nairobi
6. National Bank of Kenya, Nairobi

\section{Banks Locally Owned}

1) African Banking Corporation, Nairobi

2) African Development Bank, Nairobi

3) Akiba Bank, Nairobi

4) Bankers Trust, Nairobi

5) Biashara Bank of Kenya, Nairobi

6) Victoria Commercial Bank, Nairobi

7) CFC Bank, Nairobi

8) Transnational Bank Ltd

9) Credit Bank Ltd

10) Guardian bank Ltd

11) Investment \&Morgages Bank Ltd

12) Middle East Bank (K) Ltd

13) Akiba Bank Ltd

14) Fina Bank Ltd

15) Imperial Commercial Bank

16) Victoria Commercial Bank

17) Prime Bank Ltd

18) Equatorial Commercial Bank

19) Giro Commercial Bank

20) Biashara Bank Ltd

21) Africa Banking Corporation Ltd

22) Chase Bank Ltd

23) City Finance Bank, Nairobi

24) Commercial Bank of Africa, Nairobi

25) Continental Bank of Kenya, Nairobi

26) Cooperative Bank of Kenya, Nairob

27) East African Development Bank, Nairobi

28) Equity bank 